\title{
Reassessing the temporal evolution of orchids with new fossils and a Bayesian relaxed clock, with implications for the diversification of the rare South American genus Hoffmannseggella (Orchidaceae: Epidendroideae)
}

\author{
A Lovisa S Gustafsson ${ }^{1,2}$, Christiano F Verola ${ }^{3}$ and Alexandre Antonelli*4
}

\begin{abstract}
Background: The temporal origin and diversification of orchids (family Orchidaceae) has been subject to intense debate in the last decade. The description of the first reliable fossil in 2007 enabled a direct calibration of the orchid phylogeny, but little attention has been paid to the potential influence of dating methodology in obtaining reliable age estimates. Moreover, two new orchid fossils described in 2009 have not yet been incorporated in a molecular dating analysis. Here we compare the ages of major orchid clades estimated under two widely used methods, a Bayesian relaxed clock implemented in BEAST and Penalized Likelihood implemented in r8s. We then perform a new family-level analysis by integrating all 3 available fossils and using BEAST. To evaluate how the newly estimated ages may influence the evolutionary interpretation of a species-level phylogeny, we assess divergence times for the South American genus Hoffmannseggella (subfam. Epidendroideae), for which we present an almost complete phylogeny (40 out of 41 species sampled).

Results: Our results provide additional support that all extant orchids shared a most recent common ancestor in the Late Cretaceous ( 77 million years ago, Ma). However, we estimate the crown age of the five orchid subfamilies to be generally ( 1-8 Ma) younger than previously calculated under the Penalized Likelihood algorithm and using a single internal fossil calibration. The crown age of Hoffmannseggella is estimated here at $11 \mathrm{Ma}$, some 3 Ma more recently than estimated under Penalized Likelihood.

Conclusions: Contrary to recent suggestions that orchid diversification began in a period of global warming, our results place the onset of diversification of the largest orchid subfamilies (Orchidoideae and Epidendroideae) in a period of global cooling subsequent to the Early Eocene Climatic Optimum. The diversification of Hoffmannseggella appears even more correlated to late Tertiary climatic fluctuations than previously suggested. With the incorporation of new fossils in the orchid phylogeny and the use of a method that is arguably more adequate given the present data, our results represent the most up-to-date estimate of divergence times in orchids.
\end{abstract}

\section{Background}

Orchidaceae is the largest and one of the ecologically and morphologically most diverse families of flowering plants [1]. Several ages have been proposed for the origin of modern orchid lineages (i.e., their crown age), ranging

\footnotetext{
* Correspondence: alexandre.antonelli@vgregion.se

${ }^{4}$ Gothenburg Botanical Garden, Carl Skottsbergs gata 22A, 41319 Göteborg, Sweden

Full list of author information is available at the end of the article
}

from $\sim 26$ million years (Ma) [2], $\sim 40 \mathrm{Ma}[3], \sim 80 \mathrm{Ma}[4]$ to as much as $\sim 110 \mathrm{Ma}$ [5]. A correct time estimation is essential for our understanding of the mechanisms underlying the diversification of orchids, and could contribute to discern between alternative hypotheses of diversification - such as significant increases in speciation rates temporally correlated to climatic changes, tectonic events, or radiation of pollinators. 


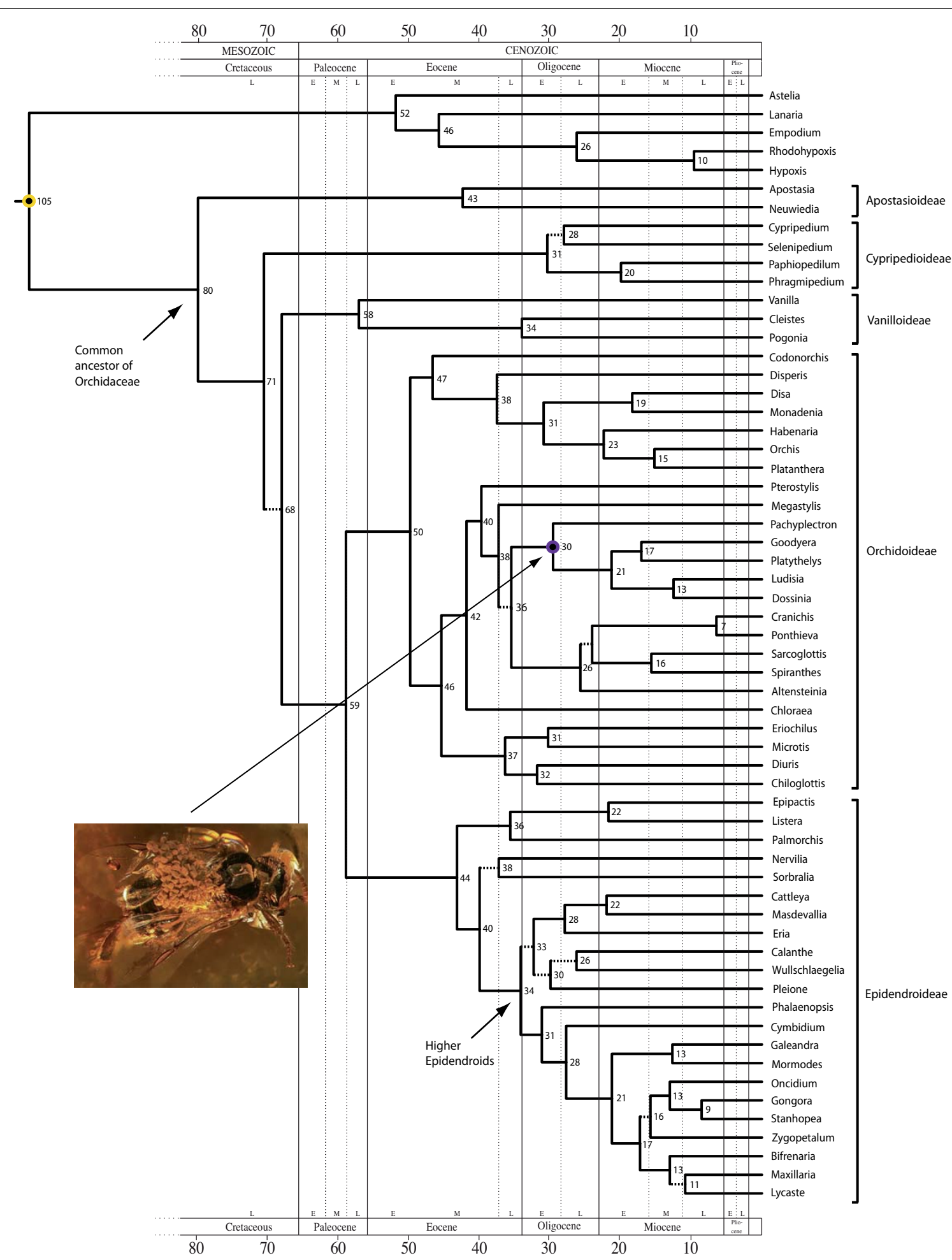

Figure 1 Time-calibrated tree of the Orchidaceae based on plastid DNA sequences (matK and $r b c \mathrm{~L}$ ), obtained with BEAST, using the same matrix and calibration points as Ramirez et al. [4]. Numbers at nodes are median ages in million of years (Ma). Dashed branches indicate nodes with Bayesian posterior probabilities below 0.90. Circles indicate age-constrained nodes; the yellow circle indicates the root node, the purple circle indicates the internal calibration point for subtribe Goodyerinae (Pachyplectron-Dossinia). Inset: The extinct stingless bee Proplebeia dominicana with well-preserved pollinia attached to the mesoscutellum; these pollinia have been demonstrated to belong to an extinct orchid species in subtribe Goodyerinae. This represents the first definitive fossil record for the Orchidaceae. Reprinted by permission from Macmillan Publishers Ltd: Nature 448(30), copyright 2007. 
Table 1: Crown group ages (in million of years) estimated for the family Orchidaceae, the five orchid subfamilies, the 'Higher Epidendroids' and the subtribe Goodyerinae, as compared to previous estimates using Penalized Likelihood .

\begin{tabular}{lccc}
\hline Clade & $\begin{array}{l}\text { Ramirez et al. [4]: Penalized } \\
\text { Likelihood }\end{array}$ & $\begin{array}{c}\text { This study: BEAST, same data } \\
\text { set as Ramirez et al. } \text { [4] }\end{array}$ & $\begin{array}{c}\text { This study: BEAST, with } \\
\text { additional taxa and } \\
\text { calibration points }\end{array}$ \\
\cline { 2 - 4 } & $\begin{array}{c}\text { Oldest \& youngest mean } \\
\text { ages ( } \pm \text { standard deviations) }\end{array}$ & Median (95\% HPD) & Median (95\% HPD) \\
\hline Family Orchidaceae & $84 \pm 6 ; 76 \pm 5$ & $80(56-105)$ & $77(63-92)$ \\
Subfamily Apostasioideae & $49 \pm 5 ; 45 \pm 4$ & $43(23-66)$ & $41(23-61)$ \\
Subfamily Vanilloideae & $71 \pm 5 ; 65 \pm 4$ & $58(39-79)$ & $57(43-72)$ \\
Subfamily Cypripedioideae & $37 \pm 4 ; 34 \pm 4$ & $31(17-49)$ & $33(19-50)$ \\
Subfamily Orchidoideae & $58 \pm 5 ; 52 \pm 4$ & $50(34-67)$ & $53(42-64)$ \\
Subfamily Epidendroideae & $59 \pm 8 ; 51 \pm 7$ & $44(29-60)$ & $49(38-62)$ \\
'Higher Epidendroids' & $50 \pm 7 ; 42 \pm 6$ & $34(22-45)$ & $39(31-49)$ \\
Subtribe Goodyerinae & $38 \pm 4 ; 34 \pm 3$ & $30(20-42)$ & $32(23-41)$ \\
Dendrobium/Earina & $\mathrm{n} / \mathrm{a}$ & $\mathrm{n} / \mathrm{a}$ & $32(25-40)$ \\
\hline
\end{tabular}

Many parameters have been identified to affect divergence time estimates in phylogenies, including taxon sampling, reliability, number and placement of internal calibration points, and dating method [6-16]. Until recently, molecular dating of the Orchidaceae has been challenging due the complete absence of reliable orchid fossils. The finding of a 15-20 Ma fossil of an extinct stingless bee (Proplebeia dominicana), covered with pollinia from an orchid species belonging to the subtribe Goodyerinae, finally allowed for temporal calibration of the family [4]. Using this fossil as an internal calibration point, and departing from a phylogenetic tree obtained from the analysis of plastid DNA sequences (matK and $r b c \mathrm{~L}$ ), Ramirez et al. [4] estimated the origin of Orchi- daceae at 76-84 Ma. These results supported an 'ancient' origin of orchids in the Late Cretaceous.

Although the study by Ramirez et al. [4] unquestionably constituted a milestone in orchid research, the large discrepancies in age estimates obtained in the last decade some $80 \mathrm{Ma}$ between the youngest [2] and oldest [5] crown ages - suggests that the matter is probably not completely settled. In a recent study in the family Begoniaceae, Goodall-Copestake et al.[16] found that the second largest source of variance in age estimates (after availability and placement of internal calibration points) was derived from the choice of dating method employed, a result consistent with previous evaluations of empirical data $[10,11]$. In particular, recent developments in molec-

Table 2: Species list for the additional species included in the new Orchidaceae dataset, with GenBank accession numbers.

\begin{tabular}{llc}
\hline Species & rbcL & matK \\
\hline $\begin{array}{l}\text { 1. Agrostophyllum majus Hook. f. } \\
\text { 2. Anigozanthos flavidus DC. }\end{array}$ & $\underline{\mathrm{AF} 518054.1}$ & $\underline{\mathrm{AY} 368391.1}$ \\
$\begin{array}{l}\text { 3. Dendrobium crystallinum Rchb. f. } \\
\text { 4. Dendrobium kingianum Bidwill ex Lindl. }\end{array}$ & $\underline{\mathrm{AJ} 404843.1}$ & $\underline{\mathrm{AF} 0887454967.1}$ \\
$\begin{array}{l}\text { 5. Dendrobium officinale Kimura \& Migo } \\
\text { 6. Earina autumnalis Hook. f. }\end{array}$ & $\underline{\mathrm{AF} 074146.1}$ & $\underline{\mathrm{AF} 263651.1}$ \\
7. Earina valida Rchb. f. & $\underline{\mathrm{FJ} 216567.1}$ & $\underline{\mathrm{FJ} 794044.1}$ \\
8. Elaeis oleifera (Kunth) Cortés & $\underline{\mathrm{AF} 074155.1}$ & $\underline{\mathrm{AF} 263656.1}$ \\
9. Musella lasiocarpa (Franch.) H.W.Li. & $\underline{\mathrm{AF} 518051.1}$ & $\underline{\mathrm{AY} 121741.1}$ \\
10. Nypa fruticans Wurmb & $\underline{\mathrm{AY} 012509.1}$ & $\underline{\mathrm{EU} 016887.1}$ \\
\hline
\end{tabular}




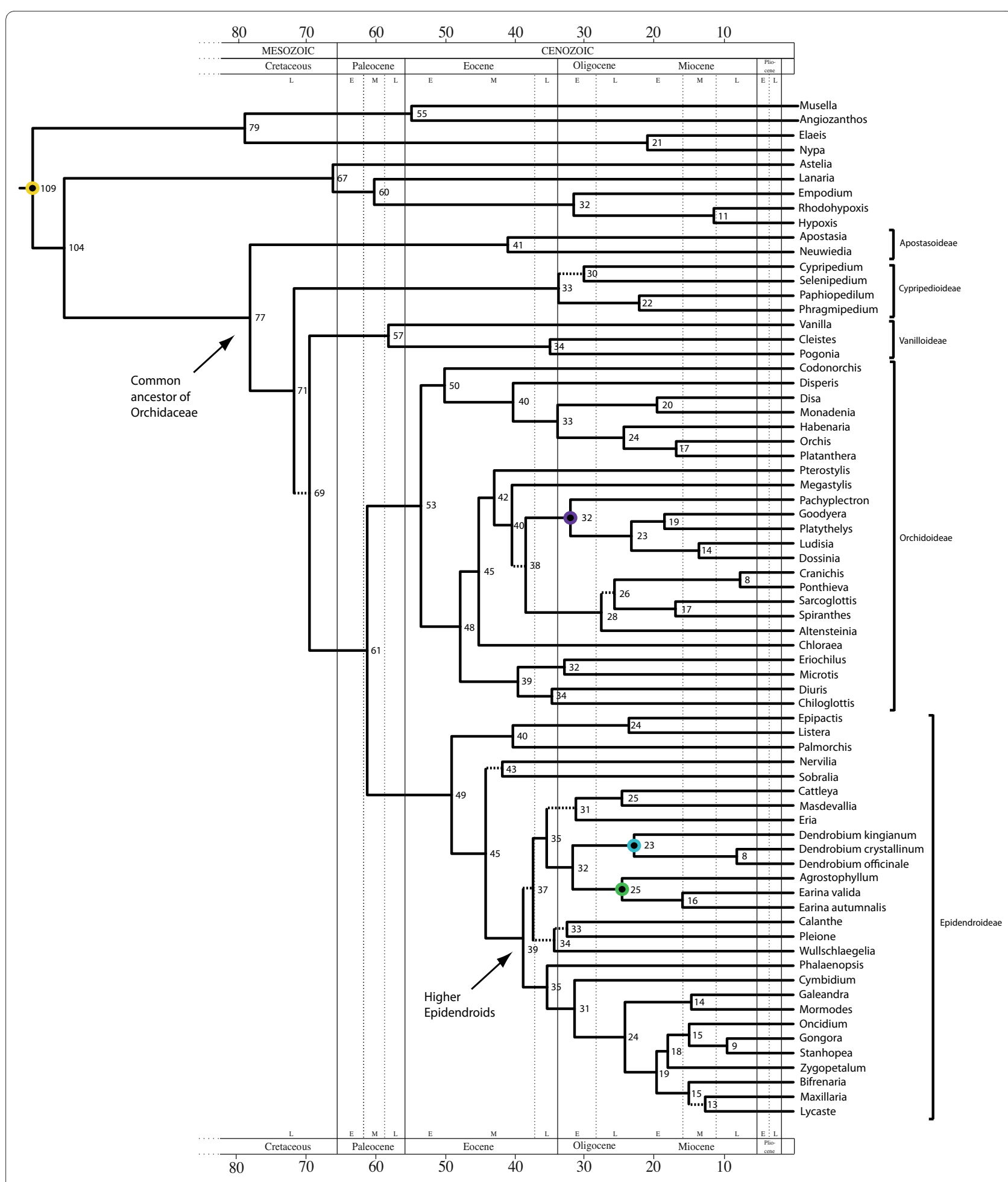

Figure 2 Time-calibrated tree of the Orchidaceae based on plastid DNA sequences (matK and $r b c \mathrm{~L}$ ) obtained with BEAST, including two new calibration points (Dendrobium and Earina), and with the root calibration on the stem node of Asparagales. Numbers at nodes are median ages in million of years (Ma). Dashed branches indicate nodes with Bayesian posterior probabilities below 0.90. Circles indicate age-constrained nodes; the yellow circle indicates the root node, the purple circle indicates the internal calibration point for subtribe Goodyerinae (Pachyplectron Dossinia), the blue circle indicates the new internal calibration point for Dendrobium and the green circle indicates the new internal calibration point for Earina. 


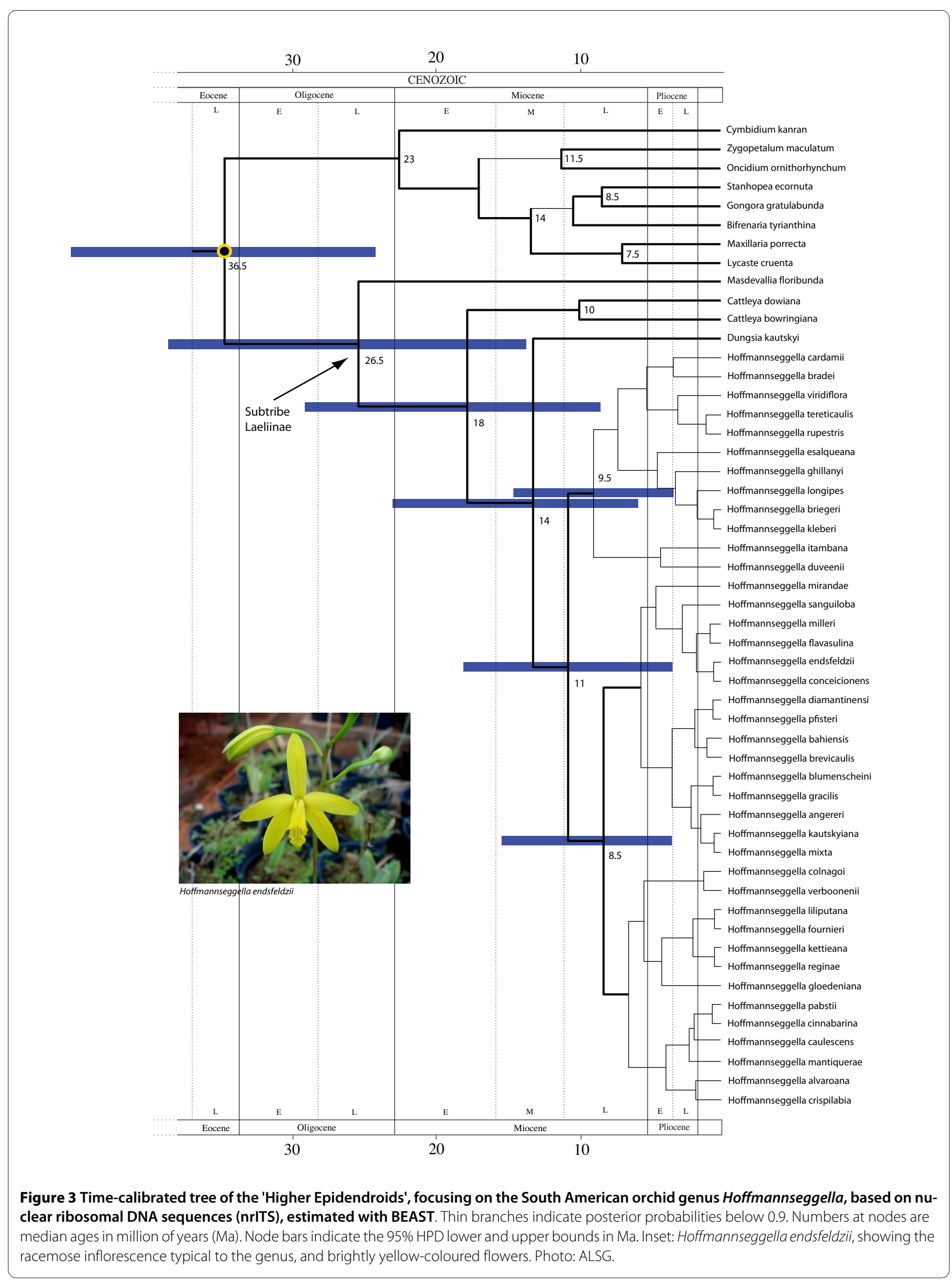




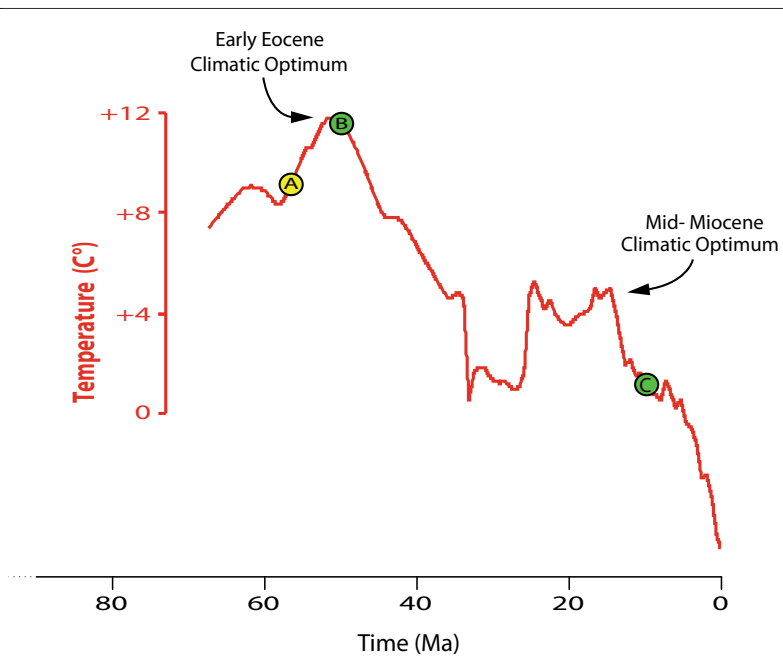

Figure 4 Temperature curve over the past 65 million years (adapted from Zachos et al. [40]), illustrating the different results obtained here using BEAST as compared to previous estimates under the Penalized Likelihood algorithm. (A): Mean age of the major diversification of Orchidaceae (subfamilies Orchidoideae and Epidendroideae) as estimated by Ramirez et al. [4] using PL. (B):

approximate median age of these clades estimated here using BEAST. (C): median age of the South American genus Hoffmannseggella in the Late Miocene, estimated here. The temperature scale is relative to the current mean global temperature ([41] provides an explanation and expanded data, but not a mean temperature curve).

ular dating techniques have called into question the assumptions and algorithms implemented in Non-parametric Rate Smoothing [NPRS; [17]] and Penalized Likelihood [PL; [18]] - the two methods employed by Ramirez et al. [4]. Whereas NPRS has been largely abandoned in favour of its successor PL [see discussion in [18]], both implemented in the software r8s [19], PL competes today in popularity with Bayesian dating [20] implemented in the software BEAST [21].

PL and BEAST operate in very different ways: i) PL requires a fixed phylogram as input, whereas BEAST samples topologies simultaneously as it calculates divergence times under a MCMC analysis, and allows the choice of several different priors and models; ii) PL assumes autocorrelation of rates within the phylogeny (i.e. that mutational rates are inherited, resulting in closely related taxa exhibiting similar evolutionary rates), whereas BEAST allows branches to vary in evolutionary rate; iii) in PL, nodes can be calibrated to be either fixed to a certain age, or constrained by a maximum or a minimal bound; whereas in BEAST, several additional alternatives are available for calibrating a node, because such calibrations represent age priors drawn from distributions of various shapes (e.g., normal, lognormal, exponential, or uniform). The methodological and conceptual differences between r8s, BEAST, and some other meth- ods available today for molecular dating have been reviewed by several authors [12,14,22-24].

Although the methodology and assumptions implemented in each molecular dating method can be readily compared, our knowledge of how time estimates are influenced by the choice of method is still poor. For instance, Goodall-Copestake et al.[16] obtained younger ages in the Begoniaceae using PL than using NPRS, but as these authors noted the inverse situation was found by Clement et al. $[25,26]$ on the same taxonomic group. According to Goodall-Copestake [16], this surprising discrepancy was probably caused by differences in density of sampled taxa and calibration points. Similarly, it may be very difficult to predict differences in age estimates using PL and BEAST: in the study by Goodall-Copestake [16], PL produced considerably younger ages than BEAST, whilst the opposite situation was found within family Caryophyllaceae [26]. These results exemplify the potential influence of methodology on age estimations.

In this study we aim at reassessing the temporal origin and diversification of Orchidaceae, using the Bayesian uncorrelated relaxed molecular clock approach implemented in BEAST. In addition to choosing a different dating method, we conduct a new analysis on an expanded taxon sampling by adding two internal calibration points in the orchid phylogeny. We base these calibrations on fossil leaves described subsequent to the study by Ramirez et al. [4] from Early Miocene deposits of New Zealand, which were confidently assigned to genera Dendrobium and Earina [27]. Then, to explore how the highlevel age estimates obtained here may affect the evolutionary interpretation of a species-level orchid clade, we date the origin and diversification of the rare South American orchid genus Hoffmannseggella.

Hoffmannseggella belongs to the Epidendroideae, the largest subfamily within Orchidaceae, which comprises over half of all orchid species [28]. The subfamily has been divided into 'lower' and 'higher' Epidendroids [29] and this latter clade includes the monophyletic subtribe Laeliinae, where Hoffmannseggella is nested [30]. The genus is endemic to Brazil, where it is confined to the High Altitude Rocky Complexes (Brazilian Campos Rupestres and Campos de Altitude) of Minas Gerais, Rio de Janeiro, Espírito Santos and Bahia states. It comprises exclusively rupicolous species, i.e. growing among rocks [31]. Adding to the 32 different species recognized by Chiron and Castro Neto [32], several new species have recently been described and today Hoffmannseggella comprises 41 species [31,33-39]. Half of these are "microendemic" - known from a single natural population, and some only from the type collection. We have been able to obtain or generate sequences for all but a single species, thus reaching a $98 \%$ complete species sampling. 

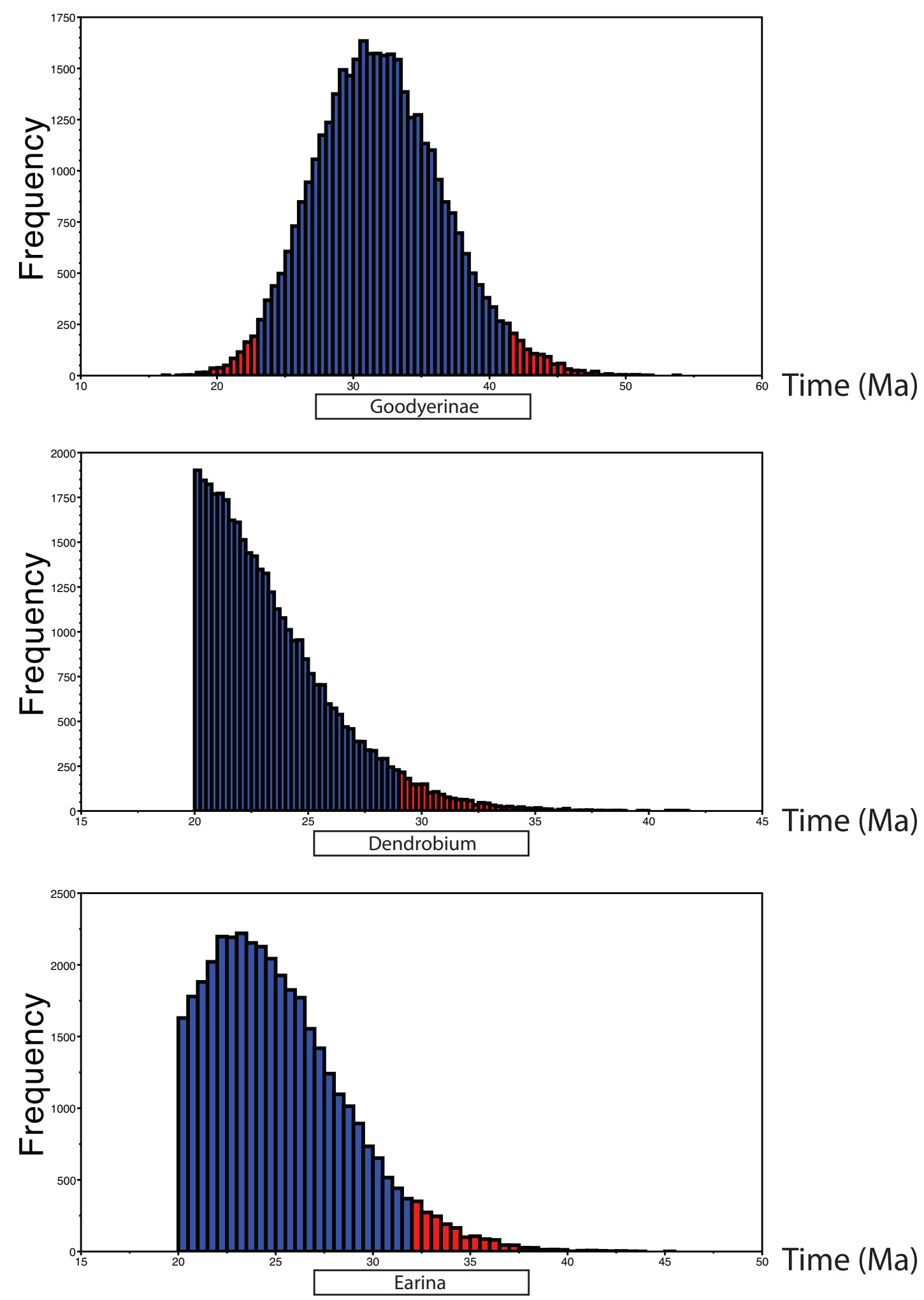

Figure 5 Posterior age distribution of the three fossil-calibrated internal nodes in the orchid phylogeny (outlined in Figure 2). The diagrams show the age of the most recent common ancestor of these nodes (in millions of years) plotted against frequency of trees, from the combined results of 5 independent BEAST runs of 20 million generations each (burn-in excluded). (A) Crown age of tribe Goodyerinae, constrained to a minimal age of $15 \mathrm{Ma}$. (B) Crown age of genus Dendrobium, constrained to a minimal age of $20 \mathrm{Ma}$. (C) Crown age of genera Earina and Agrostophyllum (in this analysis, equivalent to stem age of Earina), constrained to a minimal age of $20 \mathrm{Ma}$. 


\section{Results}

The maximum credibility tree for the fossil-calibrated relaxed molecular clock analysis of the family Orchidaceae, using the same matrix and calibration points as Ramirez et al. [4], is shown in Figure 1. Support values for the different clades and branches were high, with only a few values below 0.90 Bayesian posterior probability. Our age estimates indicate that extant Orchidaceae shared a most recent common ancestor (MRCA) in the Late Cretaceous, $\sim 80 \mathrm{Ma}$ (95\% confidence intervals, CI: 56 - 105 $\mathrm{Ma})$. Accordingly, median divergence times for the five orchid subfamilies currently recognized (Apostasioideae, Vanilloideae, Cypripedioideae, Orchidoideae and Epidendroideae) varied between $\sim 31 \mathrm{Ma}$ and $\sim 58 \mathrm{Ma}$ (Table 1 ). The most diverse orchid subfamilies Orchidoideae and Epidendroideae appear to have started to diversify in the Eocene, $50 \mathrm{Ma}$ (95\% CI: 34 - $67 \mathrm{Ma}$ ) and $44 \mathrm{Ma}$ (95\% CI: 29 - $60 \mathrm{Ma}$ ), respectively (Table 1 ).

Figure 2 shows the maximum credibility tree for the fossil-calibrated relaxed molecular clock analysis of the family Orchidaceae including the two new calibration points (Dendrobium and Earina). Also in this analysis the support values for most clades were high, with only a few values below 0.90 Bayesian posterior probability. In agreement with the previous analysis, our age estimates indicate that extant Orchidaceae shared a MRCA in the Late Cretaceous, $\sim 77 \mathrm{Ma}$ (95\% confidence intervals, CI: 63 - $92 \mathrm{Ma}$ ). Median divergence times for the five orchid subfamilies ranged from $33 \mathrm{Ma}$ to $57 \mathrm{Ma}$ (Table 1). The most diverse orchid subfamilies Orchidoideae and Epidendroideae are inferred also in this analysis to have started to diversify in the Eocene, $53 \mathrm{Ma}$ (95\% CI: 42 - 64 $\mathrm{Ma}$ ) and $49 \mathrm{Ma}$ (95\% CI: 38 - $62 \mathrm{Ma}$ ), respectively (Table 1). The median age for the crown 'Higher Epidendroids' was $39 \mathrm{Ma}$, with a $95 \% \mathrm{CI}$ of $31-49 \mathrm{Ma}$. The median divergence time for the node separating Dendrobium / Earina was $32 \mathrm{Ma}$, with a 95\% CI of 25 - $40 \mathrm{Ma}$ (Table 1).

The maximum credibility tree for the calibrated relaxed molecular clock analysis of the 'Higher Epidendroids' including the genus Hoffmannseggella is shown in Figure 3. All Hoffmannseggella species clustered together with high support value (posterior probability above 0.90), supporting the monophyly of the genus. However, the resolution within the genus was poor, mainly distinguishing two subclades. According to our dating, the genus Hoffmannseggella shared a MRCA in the Late Miocene, $\sim 11 \mathrm{Ma}$ (95\% CI: 5 - $20 \mathrm{Ma}$ ) (Figure 3).

\section{Discussion}

\section{Evolution of major orchid clades}

According to our new estimates based on the uncorrelated relaxed molecular clock approach, and incorporating three internal calibration points, extant Orchidaceae shared a MRCA in the Late Cretaceous, about $77 \mathrm{Ma}$
(95\% CI: 63 - $92 \mathrm{Ma}$ ). Except for Orchidoideae, median age estimates for the remaining orchid subfamilies are consistently younger in our study as compared to the youngest mean ages obtained by Ramirez et al. [4] (Table 1). Also in the first analysis where we used the same matrix as Ramirez et al. [4] and obtained precisely the same topology for the phylogenetic tree, median age estimates for the five orchid subfamilies are younger (Table 1).

Ramirez et al. [4] proposed a Late Palaeocene radiation ( $56 \mathrm{Ma})$ for the Orchidaceae, thus during the prominent temperature increase of the Early Cenozoic (from $59 \mathrm{Ma}$ to $52 \mathrm{Ma} ;[40,41])$. In contrast, our results suggest a younger diversification, placing the origin of the two largest orchid subfamilies Orchidoideae and Epidendroideae in the Eocene ( $\sim 53 \mathrm{Ma}$ and $\sim 49 \mathrm{Ma}$, respectively), thus at the onset of a long period of temperature decrease [40,41] (Figure 4). If these estimates are correct, a potential explanation for the initial radiation of Orchidaceae during the Eocene could be that cooler temperatures increased the global heterogeneity of ecosystems (e.g., with more open and dry habitats), creating new habitats that could foster adaptive radiation and/or increasing allopatric speciation (e.g.[42]). An alternative or complementary scenario is that the Early Eocene Climatic Optimum 51-53 Ma [40,41], when mean global temperatures reached $\sim 12^{\circ} \mathrm{C}$ higher than today's level (Figure 4), would have caused a wave of large-scale extinction and thus left many empty ecological niches available for orchid diversification.

\section{Radiation of the genus Hoffmannseggella}

Our estimate for the crown age of Hoffmannseggella indicates a Late Miocene radiation for the genus ( $11 \mathrm{Ma}$; Figure 3). This is some $3 \mathrm{Ma}$ younger than the dates obtained using a Penalized Likelihood analysis over a sample of Bayesian phylograms [43,44] (mean 14.2 Ma, 95\% CI: 9.69 - 18.6).

Antonelli et al. [44] postulated a strong correlation between climate cooling following the Mid-Miocene Climatic Optimum and range expansion and diversification in Hoffmannseggella. This younger age estimate may imply an even stronger link than originally conceived, since the intensity of climatic oscillations augmented towards the end of the Tertiary $[40,41]$.

\section{Reliability of results}

The age estimation of genus Hoffmannseggella is based on a single, secondary calibration point (the crown group age of 'Higher Epidendroids' obtained in the high-level dating analysis), which should have a direct effect on all internal divergence times. However, the node age estimations between Cattleya and Masdevallia are strikingly similar in both analyses (25 Ma in the high-level Orchi- 
Table 3: Species list for the Hoffmannseggella data set with voucher and GenBank accession numbers, indicating ITS sequences obtained from van den Berg and the species sequenced for this study.

\begin{tabular}{|c|c|c|c|c|}
\hline Species & Voucher & GenBank No. & Included in [28]. & New sequences \\
\hline 1. H. alvaroana F. E. L. Miranda & van den Berg C227 (ESA) & $\underline{\text { AY008672 }}$ & $x$ & \\
\hline 2. H. angereri Pabst & C223-Machado s. n. (ESA) & $\underline{\text { AY008652 }}$ & $x$ & \\
\hline 3. H. bahiensis Schultr. & C221-Machado s. n. (ESA) & $\underline{\text { AY008653 }}$ & $\mathrm{x}$ & \\
\hline 4. H. blumenscheinii Pabst & C209-Machado s. n. (ESA) & $\underline{\text { AY008654 }}$ & $\mathrm{x}$ & \\
\hline 5. H. bradei Pabst & C215-Machado s. n. (ESA) & $\underline{\text { AY0008673 }}$ & $x$ & \\
\hline 6. H. brevicaulis (H. G. Jones) Withner & C208-Machado s. n. (ESA) & $\underline{\text { AY0008655 }}$ & $x$ & \\
\hline 7. H. briegeri Blumensch. ex Pabst & Brieger Coll. 4612 (ESA) & $\underline{\text { AY008674 }}$ & $x$ & \\
\hline 8. H. cardimii Pabst \& A. F. Mello & C205-Machado s. n. (ESA) & $\underline{\text { AY008675 }}$ & $x$ & \\
\hline 9. H. caulescens Lindl. & Brieger Coll. 1916 (ESA) & $\underline{\text { AY008656 }}$ & $\mathrm{x}$ & \\
\hline 10. H. cinnabarina Batem. Ex Lindl & Brieger Coll. 1395 (ESA) & $\underline{\text { AY008657 }}$ & $\mathrm{x}$ & \\
\hline 11. H. colnagoi Chiron \& astro & A. L. S. Gustafsson 09 (GB) & $\underline{F J 200183}$ & & $x$ \\
\hline 12. H. conceicionensis Castro \& ampacci & A. L. S. Gustafsson 14 (GB) & $\underline{\text { FJ200196 }}$ & & $x$ \\
\hline 13. H. crispilabia (A. Rich. ex Rchb. f.) Warner & Brieger Coll. 4837 (ESA) & AY008659 & $x$ & \\
\hline 14. H. diamantinensis Castro \& Marçal & A. L. S. Gustafsson 08 (GB) & FJ200187 & & $x$ \\
\hline 15. H. duveenii Fowlie & C213-Machado s. n. (ESA) & $\underline{\text { AY008671 }}$ & $\mathrm{x}$ & \\
\hline 16. H. endsfeldzii (Pabst) Castro \& hiron & A. L. S. Gustafsson 06 (GB) & FJ200190 & & $x$ \\
\hline 17. H. esalqueana Blumensch. Ex Pabst & Brieger Coll. 4980 (ESA) & AF260198 & $x$ & \\
\hline 18. H. flavasulina Miranda \& acerda & A. L. S. Gustafsson 05 (GB) & $\underline{F J 200186}$ & & $x$ \\
\hline 19. H. fournieri (Cogniaux) Castro \& hiron & A. L. S. Gustafsson 01 (GB) & FJ200185 & & $\mathrm{x}$ \\
\hline 20. H. ghillanyi Pabst & C214-Machado s. n. (ESA) & $\underline{\text { AY008677 }}$ & $\mathrm{x}$ & \\
\hline 21. H.gloedeniana Hoehne & van den Berg C35(ESA) & $\underline{\text { AY008666 }}$ & $x$ & \\
\hline 22. H. gracilis (Pabst) Castro \& hiron & A. L. S. Gustafsson 04 (GB) & FJ200191 & & $\mathrm{x}$ \\
\hline 23. H. itambana Pabst & C-Machado s. n. (ESA) & $\underline{\text { AY008678 }}$ & $\mathrm{x}$ & \\
\hline 24. H. kautskyana Castro \& hiron & A. L. S. Gustafsson 10 (GB) & $\underline{F J 200188}$ & & $x$ \\
\hline 25. H. kettieana Pabst & C210-Machado s. n. (ESA) & $\underline{\text { AY008664 }}$ & $x$ & \\
\hline 26. H. kleberi Miranda & A. L. S. Gustafsson 11 (GB) & FJ200194 & & $x$ \\
\hline 27. H. liliputana Pabst & A. L. S. Gustafsson 03 (GB) & FJ200189 & & $\mathrm{x}$ \\
\hline 28. H. longipes Rchb. f. & Brieger Coll. 5183 (ESA) & $\underline{\text { AY008676 }}$ & $\mathrm{x}$ & \\
\hline 29. H. mantiqueirae Pabst ex D. C. Zappi & van den Berg C224 (ESA) & $\underline{\text { AY008663 }}$ & $\mathrm{x}$ & \\
\hline 30. H. milleri Blumensch. ex Pabst & Brieger Coll. 5070 (ESA) & $\underline{\text { AY008661 }}$ & $\mathrm{x}$ & \\
\hline 31. H. mirandae Lacerda \& astro & A. L. S. Gustafsson 07 (GB) & $\underline{F J 200193}$ & & $x$ \\
\hline 32. H. mixta Hoehne ex Ruschi & C220-Machado s. n. (ESA) & $\underline{\text { AY008660 }}$ & $x$ & \\
\hline 33. H. pabstii Miranda \& acerdo & A. L. S. Gustafsson 12 (GB) & $\underline{F J 200184}$ & & $x$ \\
\hline 34. H. pfisteri Pabst \& Senghas & van den Berg C226 (ESA) & $\underline{\text { AY008662 }}$ & $\mathrm{x}$ & \\
\hline 35. H. presidentensis Camacci & not available for sequencing & & & \\
\hline 36. H. reginae Pabst & C218-Machado s. n. (ESA) & $\underline{\text { AY008668 }}$ & $x$ & \\
\hline 37. H. rupestris Lindl. & van den Berg C33 (ESA) & data missing & $\mathrm{x}$ & \\
\hline 38. H. sanguiloba Withner & C216-Machado s. n. (ESA) & $\underline{\text { AY008669 }}$ & $\mathrm{x}$ & \\
\hline 39. H. tereticaulis Hoehne & van den Berg C222 (ESA) & AY008670 & $x$ & \\
\hline 40. H. verboonenii (Miranda) Castro \& hiron & A. L. S. Gustafsson 13 (GB) & FJ200192 & & $x$ \\
\hline 41. H. viridiflora Verola \& Semir & A. L. S. Gustafsson 02 (GB) & $\underline{F J 200195}$ & & $\mathrm{x}$ \\
\hline 42. Cattleya dowiana Batem & Chase $0-282(\mathrm{~K})$ & AF260210 & (X) only $r b c L$ & \\
\hline
\end{tabular}


Table 3: Species list for the Hoffmannseggella data set with voucher and GenBank accession numbers, indicating ITS sequences obtained from van den Berg and the species sequenced for this study. (Continued)

\begin{tabular}{|c|c|c|c|}
\hline 43. Cattleya bowringiana Veitch & Brieger Coll. 96 (ESA) & $\underline{\text { AY008585 }}$ & \\
\hline 44. Dungsia kautskyi Pabst & van den Berg C286 (K spirit) & AY008651 & \\
\hline 45. Masdevallia floribunda Lindl. & Chase 0-296 (K) & AF260146 & $x$ \\
\hline 46. Cymbidium kanran Makino & data missing & AF284720 & \\
\hline 47. Oncidium ornithorhynchum Kunth & data missing & AF239400 & \\
\hline 48. Gongora gratulabunda Rchb.f. & data missing & AF239382 & \\
\hline 49. Stanhopea ecornuta Lem. & data missing & AF239349 & \\
\hline 50. Zygopetalum maculatum (Kunth) Garay & Chase $160(\mathrm{~K})$ & $\underline{\text { AY870097 }}$ & \\
\hline 51. Bifrenaria tyrianthina Rchb. f. & data missing & $\underline{\mathrm{DQ} 210235}$ & \\
\hline 52. Maxillaria porrecta Lindl. & data missing & $\underline{\mathrm{DQ} 210568}$ & \\
\hline 53. Lycaste cruenta Lindl. & data missing & AF239342 & \\
\hline
\end{tabular}

daceae data set, CI:14 - 35; and $26.5 \mathrm{Ma}$ in the Hoffmannseggella data set, CI: 14 - 41). This agreement provides some cross-validation for the use of the 'Higher Epidendroids' as a calibration point for the Hoffmannseggella data set.

As outlined in the Introduction, PL and BEAST make different evolutionary assumptions and have very different algorithms. This precludes categorical assertions on which of these methods yields the most correct divergence time estimates. One way to assess the autocorrelation assumption made by PL is to examine the covariance between parent and child branch in each phylogeny. This value is calculated by the software Tracer v1.4 [45] from the log files of the MCMC analyses, and should be significantly positive when rates are autocorrelated, and near zero when there is no evidence of autocorrelation (see BEAST manual). For the Orchidaceae data set, this covariance had a mean of 0.10 and $95 \%$ confidence intervals ranging from -0.05 to 0.26 . Although the covariance has been criticized as a weak measure of autocorrelation and more critical discussion on this subject is needed [46], the low covariance found in this study does not provide positive evidence for autocorrelation, thus favouring the BEAST results reported here.

\section{Influence of internal fossil calibrations}

It is worth noting that the single fossil used by Ramirez et al. [4], for tribe Goodyerinae, did not influence any age estimates for Orchidaceae in the BEAST analysis. This is evident by examining the distribution of ages of the MRCA of tribe Goodyerinae, which falls outside the lower age prior of $15 \mathrm{Ma}$ (Figure 5a). In contrast, both New Zealand fossils affected age estimates, as is apparent from the age distributions of the two constrained nodes, truncated at their younger bound $20 \mathrm{Ma}$ (Figure 5b, c). While the Dendrobium crown age constraint was most frequently reached during the analyses (Figure 5b), the Earina stem age constraint was often reached but did not prevent a normally distributed age distribution with a mean older than the fossil constraint (Figure 5c).

\section{Conclusions}

Molecular dating techniques have greatly improved in the last years, offering novel opportunities to study the temporal evolution of taxa. However, it is essential to critically evaluate the impact of methodology and other parameters (taxon sampling, fossil calibrations, sequence regions) on the reliability of results. This study has shown that age estimations for orchid clades vary by several million years when using BEAST or Penalized Likelihood. While the addition of two new internal calibration points makes our study the most up-to-date estimate of the temporal evolution of orchids, additional studies may be required before a stable chronogram of this charismatic plant family is achieved.

\section{Methods}

\section{Taxon sampling and genetic markers}

In the first analysis for the Orchidaceae family, we used the matrix compiled by Ramirez et al. [4], including aligned plastid DNA sequences (matK and $r b c \mathrm{~L}$ ). The matrix comprised 60 taxa and 2858 characters (see [4] for a detailed list of included species and GenBank accession numbers). In the second dating analysis of the Orchidaceae, we used six additional taxa, including sequences of both matK and $r b c \mathrm{~L}$, to allow the use of two recently described orchid fossils from New Zealand as calibration points. We also added sequences from four new outgroup genera, which enabled us to use the stem node of Asparagales as root calibration point, instead of the crown node, as done by Ramirez et al. [4]. We did this because the oldest fossil used by Ramirez et al. [4] was Liliacidites sp., which does not have any diagnostic features of crown Asparagales. The additional sequences were re-aligned with those of Ramirez et al. [4], using MAFFT version 
5.64 [47]. The final matrix comprised 70 taxa and 2905 characters (see Table 2 for the additional species and their corresponding GenBank accession numbers).

For Hoffmannseggella, 40 out of 41 species were sampled (Table 3). The ITS region (ITS1-5.8S-ITS2) was sequenced for 14 species to complement the study by van den Berg et al. [30]. The matrix, including outgroup species selected on the basis of previous phylogenetic analyses $[4,30]$, comprised 56 taxa and 660 characters. No gaps were coded in any of the matrices.

\section{DNA extraction, amplification and sequencing}

Total genomic DNA was extracted exclusively from fresh plant material using a $2 \%$ CTAB protocol (adapted from [48]). Amplification was performed using PuReTaq ${ }^{\text {Im }}$ Ready-To-Go ${ }^{\text {mm}} \mathrm{PCR}$ beads (Amersham Biosciences) for $25 \mu \mathrm{L}$ reactions using $20 \mathrm{pmol}$ of each primer. The two primers used were 'P17' (5'-CTACCGATTGAATGGTCCGGTGAA-3') and '26S-82R' (5'-TCCCGGTTCG CTCGCCGTTACTA3') of [49]. PCR-products were analysed by electrophoresis using a $1 \%$ agarose gel and purified using QIAquick PCR Purification Spin Columns $\left(\right.$ QIAGEN $\left.^{\circ}\right)$. Quantification of the PCR-products was then done using GeneQuant II (Pharmacia Biotech).

Sequencing was performed using a $\mathrm{CEQ}^{\mathrm{m}} 8000$ (Genetic Analysis System, software 8.0, Beckham Coulter ) automated sequencer. Reactions were made with GenomeLab $^{\mathrm{mm}}$ DTCS-Quick Start Kit (Beckham Coulter $\left.{ }^{\circ}\right)$ according to manufacturer's instructions, except that 10 $\mu \mathrm{L}$ reactions were used, with $50 \mathrm{ng}$ template and $1.6 \mathrm{pmol}$ per reaction. The two primers used for sequencing ITS were 'P16b' (5'-CCAYTGAACCTTATCATTKAGAGGA3') of [50] and 'ITS4R' (5'- TCCTCCGCTTATTGATATGC-3') of [51]. Editing and compilation of the sequences was done using Sequencher ${ }^{\mathrm{m}}$ version 4.1 (Gene Codes Corporation).

\section{Sequence alignment and dating analyses}

The matrix for Orchidaceae [4] was analysed using a relaxed molecular clock approach with the software BEAST v1.5.3 [21]. The input data were compiled in BEAUti v1.5.3 with the tree priors set as follows: $i$ ) age for the monophyletic subtribe Goodyerinae (corresponding to the age of the fossil orchid pollinia 15 - 20 Ma old; [4]): uniform prior distribution with a lower bound of $15 \mathrm{Ma}$ and an upper bound of $120 \mathrm{Ma}$; ii) age for the root of the tree (corresponding to the oldest known fossil record for Asparagales; see discussion in [4]): normal prior distribution with mean $106.5 \mathrm{Ma}$ and standard deviation of 8.21 (giving a 95\% CI ranging from 93 - $120 \mathrm{Ma}$ ). The second family-level matrix (with the additional taxa) was analysed with the following tree priors: $i$ ) age for the monophyletic subtribe Goodyerinae set as above; ii) the two additional calibration points for Dendrobium and Earina set as uniform prior distributions with a lower bound of $20 \mathrm{Ma}$ and an upper bound of $120 \mathrm{Ma}$ (phylogenetic placement following [27]); iii) age for the root of the tree set to an uniform prior distribution with a lower bound of $93 \mathrm{Ma}$ and an upper bound of $120 \mathrm{Ma}$. The upper (maximum) age constraint of $120 \mathrm{Ma}$ for the calibrations above corresponds to the oldest known monocot fossils [52]. We acknowledge that this constraint may be questionable since fossils generally provide minimal ages, but in absence of further evidence such upper bounds are technically advantageous for preventing the root of the tree to assume unreasonably old ages.

The ITS sequences generated here for 14 Hoffmannseggella species were completely re-aligned with those of van den Berg et al. [30], along with outgroup sequences from the 'Higher Epidendroids' downloaded from GenBank. The alignment was performed using MAFFT version 5.64 [47]. The age for the root of the tree was set to a normal prior distribution with mean $39 \mathrm{Ma}$ and standard deviation of 5.5 (giving a 95\% CI ranging from c. $31-49 \mathrm{Ma}$ ) corresponding to the resulting age estimate for the 'Higher Epidendroids' in the second analysis of the Orchidaceae matrix (see under Results).

The Yule process was chosen as speciation process for all three data sets. The Akaike Information Criterion in MrModelTest v2.3 [53] was used to choose the best-fitting evolutionary model for each sequence region $(\mathrm{GTR}+\Gamma+\mathrm{I}$ for both partitions in the Orchidaceae data set and GTR $+\Gamma$ for ITS in the Hoffmannseggella data set). Five separate runs were performed in BEAST with 20 million generations each. Log files were analysed with Tracer v1.5 [45], to assess convergence and confirm that the combined effective sample sizes for all parameters were larger than 200, in order to ensure that the MCMC chain had run long enough to get a valid estimate of the parameters [54]. All resulting trees were then combined with LogCombiner v1.5.3, with a burn-in of $25 \%$. A maximum credibility tree was then produced using TreeAnnotator v1.5.3 [21].

\section{Abbreviations}

BEAST: Bayesian evolutionary analysis by sampling trees; $\mathrm{Cl}$ : confidence interval; HPD: highest posterior density; Ma: million years (from mega-annum); MRCA: most recent common ancestor; PL: Penalized Likelihood.

\section{Authors' contributions}

ALSG and AA designed the study; ALSG and CFV conducted fieldwork; ALSG generated molecular data and conduced data analysis; ALSG and AA interpreted the results and wrote the paper. All authors read and approved the final manuscript.

\section{Acknowledgements}

We thank Santiago Ramirez for providing us with the molecular data set for Orchidaceae; Bengt Oxelman, Christian Parisod, Bente Eriksen, Anne-Cathrine Scheen, Vivian Aldén, Mats Töpel, Magnus Popp and Kaiser Schwarcz for their various help during this project; Andrew Rambaut for advice using BEAST; Maria do Rosário de Almeida Braga, Tim Moulton and Glauco Batalha Altman for their kind help in Petrópolis, Brazil; Hervé Sauquet, two anonymous review- 
ers and the associate editor for constructive criticism; and the Swedish Research Council (grant to Claes Persson) and the Carl Skottbergs foundation (travel grant to ALSG) for financial support.

\section{Author Details}

'Department of Plant and Environmental Sciences, University of Gothenburg, Box 461, SE-405 30, Göteborg, Sweden, ${ }^{2}$ Current Address: National Centre for Biosystematics, Natural History Museum, University of Oslo, P.O. Box 1172 Blindern, 0318 Oslo, Norway, ${ }^{3}$ Departamento de Botânica e Ecologia, Instituto de Biociências, Universidade Federal de Mato Grosso, Cuiabá, Av. Fernando Corrêa da Costa s/n, Cuiabá, CEP 78060-900, Mato Grosso, Brazil and ${ }^{4}$ Gothenburg Botanical Garden, Carl Skottsbergs gata 22A, 41319 Göteborg, Sweden

Received: 21 August 2009 Accepted: 14 June 2010

Published: 14 June 2010

\section{References}

1. Dressler RL: The Orchids, natural history and classification. Cambridge: Harward University Press; 1990.

2. Wikström N, Savolainen V, Chase MW: Evolution of the Angiosperms: Calibrating the family tree. Proceedings of the Royal Society of London. Biological Sciences 2001, 268:2211-2220.

3. Bremer K: Early Cretaceous lineages of monocot flowering plants. Proceedings of the National Academy of Sciences of the United States of America 2000, 97(9):4707-4711.

4. Ramirez SR, Gravendeel B, Singer RB, Marshall CR, Pierce NE: Dating the origin of the Orchidaceae from a fossil orchid with its pollinator. Nature 2007, 448:1042-1045.

5. Janssen T, Bremer $\mathrm{K}$ : The age of major monocot groups inferred from $800+\mathrm{rbcL}$ sequences. Botanical Journal of the Linnean Society 2004:385-398

6. Anderson CL, Bremer K, Friis EM: Dating phylogenetically basal eudicots using rbcL sequences and multiple fossil reference points. American Journal of Botany 2005, 92(10):1737-1748.

7. Bell CD, Soltis DE, Soltis PS: The age of the Angiosperms: A molecular timescale without a clock. Evolution 2005, 59(6):1245-1258.

8. Bromham L, Woolfit M: Explosive radiations and the reliability of molecular clocks: Island endemic radiations as a test case. Systematic Biology 2004, 53(5):758-766.

9. Hug LA, Roger AJ: The impact of fossils and taxon sampling on ancient molecular dating analyses. Molecular biology and evolution 2007 24(8):1889-1897.

10. Linder HP, Hardy CR, Rutschmann F: Taxon sampling effects in molecular clock dating: An example from the African Restionaceae. Molecular Phylogenetics and Evolution 2005, 35(3):569-582.

11. Pirie MD, Chatrou LW, Mols JB, Erkens RHJ, Oosterhof J: 'Andean-centred' genera in the short-branch clade of Annonaceae: Testing biogeographical hypotheses using phylogeny reconstruction and molecular dating. Journal of Biogeography 2006, 33(1):31-46.

12. Renner SS: Relaxed molecular clocks for dating historical plant dispersal events. Trends in Plant Science 2005, 10(11):550-558.

13. Ricklefs RE: Estimating diversification rates from phylogenetic information. Trends in Ecology and Evolution 2007, 22(11):601-610.

14. Rutschmann F: Molecular dating of phylogenetic trees: A brief review of current methods that estimate divergence times. Diversity and Distributions 2006, 12(1):35-48.

15. Sanders KL, Lee MSY: Evaluating molecular clock calibrations using Bayesian analyses with soft and hard bounds. Biology letters 2007, 3(3):275-279.

16. Goodall-Copestake WP, Harris DJ, Hollingsworth PM: The origin of a mega-diverse genus: dating Begonia (Begoniaceae) using alternative datasets, calibrations and relaxed clock methods. Botanical Journal of the Linnean Society 2009, 159(3):363-380

17. Sanderson MJ: A nonparametric approach to estimating divergence times in the absence of rate constancy. Molecular biology and evolution 1997, 14(12):1218-1231.

18. Sanderson MJ: Estimating absolute rates of molecular evolution and divergence times: a Penalized Likelihood approach. Molecular Biology and Evolution 2002, 19:101-109.
19. Sanderson MJ: r8s: inferring absolute rates of molecular evolution and divergence times in the absence of a molecular clock. Bioinformatics 2003, 19(2):301-302.

20. Drummond AJ, Ho SYW, Phillips MJ, Rambaut A: Relaxed phylogenetics and dating with confidence. PLoS Biology 2006, 4(5):e88.

21. Drummond AJ, Rambaut A: BEAST: Bayesian evolutionary analysis by sampling trees. BMC Evolutionary Biology 2007, 7:214.

22. Pulquério MJF, Nichols RA: Dates from the molecular clock: how wrong can we be? Trends in Ecology \& Evolution 2007, 22(4):180-184.

23. Magallón SA: Dating lineages: Molecular and paleontological approaches to the temporal framework of clades. International Journal of Plant Sciences 2004, 165(S4):S7-S21.

24. Sanderson MJ, Thorne JL, Wikström N, Bremer K: Molecular evidence on plant divergence times. American Journal of Botany 2004, 91(10):1656-1665.

25. Clement WL, Tebbitt MC, Forrest LL, Blair JE, Brouillet L, Eriksson T, Swensen SM: Phylogenetic position and biogeography of Hillebrandia sandwicensis (Begoniaceae): A rare Hawaiian relict. American Journal of Botany 2004, 91(6):905-917.

26. Frajman B, Eggens F, Oxelman B: Hybrid origins and homoploid reticulate evolution within Heliosperma (Sileneae, Caryophyllaceae) A multigene phylogenetic approach with relative dating. Systematic Biology 2009, 58(3):328-345.

27. Conran JG, Bannister JM, Lee DE: Earliest orchid macrofossils: Early Miocene Dendrobium and Earina (Orchidaceae: Epidendroideae) from New Zealand. American Journal of Botany 2009, 96(2):466-474.

28. Dressler RL: Phylogeny and classification of the orchid family. Portland Oregon: Dioscorides Press; 1993

29. Cameron KM, Chase MW, Whitten WM, Kores PJ, Jarrell DC, Albert VA Yukawa T, Hills HG, Goldman DH: A phylogenetic analysis of the Orchidaceae: evidence from $\mathrm{rbcL}$ nucleotide sequences. American Journal of Botany 1999, 86(2):208-224.

30. Van den Berg C, Higgins WE, Dressler RL, Whitten WM, Soto Arenas M, Culham A, Chase MW: A phylogenetic analysis of laeliinae (orchidaceae) based on sequence data from internal transcribed spacers (ITS) of nuclear ribosomal DNA. Lindleyana 2000, 15:96-114.

31. Verola CF, Semir J: Hoffmannseggella viridiflora (Orchidaceae, Laeliinae), a new species from Brazilian campus rupestris. Novon 2007, 17:125-129

32. Chiron GR, Castro Neto VP: Mudança de nomenclatura dentro do gênero Laelia Lindl. Richardiana 2002, 2:4-28.

33. Campacci MA: Duas novas especies de orquideas do Brasil. Boletim CAOB 2005, 57:24-31.

34. Castro Neto VP, Chiron GR: Une nouvelle espèce d'Hoffmannseggella (Orchidaceae) du Brésil. Richardiana 2003, 3:64-68.

35. Chiron GR, Castro Neto VP: Contribution à la connaissance des orchidées du Brésil. VI - Une nouvelle espèce de Hoffmannseggella du Minas Gerais (Brésil). Richardiana 2005:7-15

36. Lacerda KG, Castro Neto VP: Deux nouveaux taxons de Hoffmannseggella du Minas Gerais (Brésil). Richardiana 2005, 5:15-25.

37. Miranda F: Studies in Brazilian Laeliinae. Part 2: A New species in Hoffmannseggella. Orchids 2005, 74:458-461.

38. Miranda F, Lacerda KG: Studies in Brazilian Laeliinae. Part 1: New species and natural hybrids in Hoffmannseggella. Orchids 2003, 72:848-857.

39. Mota RC, Viana PL, Lacerdo KG: Hoffmannseggella pendula, une nouvelle espèce d'Orchidaceae du Brésil. Richardiana 2003, 4:1-8.

40. Zachos J, Pagani M, Sloan L, Thomas E, Billups K: Trends, rhythms, and aberrations in Global Climate 65 Ma to present. Science 2001, 292:686-693.

41. Zachos JC, Dickens GR, Zeebe RE: An early Cenozoic perspective on greenhouse warming and carbon-cycle dynamics. Nature 2008, 451(7176):279-283.

42. Haffer J: Alternative models of vertebrate speciation in Amazonia: An overview. Biodiversity and Conservation 1997, 6(3):451-476.

43. Verola CF, Semir J, Antonelli A, Koch I: Biosystematic studies in Brazilian endemic genus Hoffmannseggella H.G.Jones (Orchidaceae: Laeliinae) a multiple approach applied to conservation. Lankesteriana 2007, 7(12):419-422.

44. , Verola CF, Gustafsson ALS: Climate cooling promoted the expansion and radiation of a threatened group of South American orchids (Epidendroideae: Laeliinae). Biological Journal of the Linnean Society 2010, 100(3):596-606. 
45. Rambaut A, Drummond AJ: Tracer v1.4. 2007 [http://beast.bio.ed.ac.uk/ Tracer].

46. Ho SYW: An examination of phylogenetic models of substitution rate variation among lineages. Biology letters 2009, 5(3):421-424.

47. Katoh K, Kuma K-I, Toh H, Miyata T: MAFFT version 5: improvement in accuracy of multiple sequence alignment. Nucleic Acid Research 2005, 33(2):511-518.

48. Steward CN, Via LE: A rapid CTAB DNA isolation technique useful for RAPD fingerprinting and other PCR applications. BioTechniques 1993, 14(5):748-749.

49. Popp M, Oxelman B: Inferring the history of the polyploidy Silene aegaea (Caryophyllaceae) using plastid and homoeologous nuclear DNA sequences. Molecular Phylogenetics and Evolution 2001, 20(3):474-481.

50. Popp M, Eggens F, Erixon P, Oxelman B: Origin and evolution of a circumpolar polyploidy species complex in Silene (Caryophyllaceae) inferred from low copy nuclear RNA polymerase introns, rRNA, and chloroplast DNA. Systematic Botany 2005, 30(2):302-313.

51. White TJ, Bruns T, Lee S, Taylor JW: Amplification and direct sequencing of fungal ribosomal RNA genes for phylogenetics. In PCR protocols: a guide to methods and applications Edited by: Innis MA, Gelfand DH, Sninsky JJ, White TJ, Innis MA, Gelfand DH, Sninsky JJ, White TJ. New York, N.Y: Academic Press, Inc; 1990:315-322.

52. Friis EM, Pedersen KR, Crane PR: Araceae from the Early Cretaceous of Portugal: Evidence on the emergence of monocotyledons. Proc Natl Acad Sci USA 2004, 101(47):16565-16570.

53. Nylander JAA: MrModeltest v2. Program distributed by the author. Evolutionary Biology Centre, Uppsala University 2004.

54. Drummond AJ, Ho SYH, Rawlence HN, Rambaut A: A rough guide to BEAST 1.4. 2007 [http://beast.bio.ed.ac.uk/Main Page].

doi: 10.1186/1471-2148-10-177

Cite this article as: Gustafsson et al., Reassessing the temporal evolution of orchids with new fossils and a Bayesian relaxed clock, with implications for the diversification of the rare South American genus Hoffmannseggella (Orchidaceae: Epidendroideae) BMC Evolutionary Biology 2010, 10:177

Submit your next manuscript to BioMed Central and take full advantage of:

- Convenient online submission

- Thorough peer review

- No space constraints or color figure charges

- Immediate publication on acceptance

- Inclusion in PubMed, CAS, Scopus and Google Scholar

- Research which is freely available for redistribution

Submit your manuscript at www.biomedcentral.com/submit
C) BioMed Central 